\title{
Kayseri İl Merkezinde Doğum Yapan Kadınların Doğum Öncesi Bakım Alma Durumu ve Etkileyen Faktörler
}

\section{Prenatal Care Status and Affecting Factors of Women who Delivered in Kayseri Province}

\section{Ayşegül ERDOĞAN ${ }^{1}$, Fevziye ÇETINKAYA ${ }^{2}$}

${ }^{1}$ Dr.Öğr.Üyesi. Kahramanmaraş Sütçü İmam Üniversitesi Tip Fakültesi, Halk Sağlığı Anabilim Dalı, KAHRAMANMARAŞ

${ }^{2}$ Prof. Dr. Erciyes Üniversitesi Tıp Fakültesi, Halk Sağlı̆̆ı Anabilim Dalı, KAYSERİ

\section{Özet}

Amaç: Kadınların doğum öncesi bakım alma düzeyinin belirlenmesi ve doğum öncesi bakımın yeterliliğini etkileyen faktörlerin saptanmasidir.

Gereç ve Yöntemler: Tanımlayıcı tipte olan bu araştırma Kayseri İl merkezinde yürütülmüştür. Örneklem büyüklüğü \%95 güven düzeyinde, $\% 80$ güç ile $\% 7$ toleransla 501 kişi olarak hesaplanmıştır. Araştırma kapsamına 650 kadının alınması hedeflenmiştir. 627 kadına ulaşılmış olup ulaşma oranı \%96,5'dir. Çalışmanın gücü \%87 olarak bulunmuştur. Veri toplama yöntemi olarak anket formu kullanılmış olup; veriler Haziran-Temmuz 2002 ve Ekim-Kasım 2002 tarihleri arasında toplanmıştır.

Bulgular: Araştırma grubuna alınan 627 kadının yaş ortalaması 25,5 $\pm 5,2$ bulunmuştur. Araştırma grubundaki kadınların \%97,5’ $\mathrm{i}$ en az bir kez doğum öncesi bakım aldığı, \%62,4'ünün ise yeterli doğum öncesi bakım aldığı bulunmuştur. Tüm değişkenler kontrol edildiğinde, yerleşim yeri, kadının eğitimi, eşin eğitimi, aile tipi, sosyal güvence ve gebeliğin istenme durumu, yeterli doğum öncesi bakım almada önemli birer belirleyici faktör olarak bulunmuştur.

Sonuç: DÖB hizmetlerinin kullanımında kadının statüsünün geçmişte oldukça önemli olduğu, yıllar içinde de kadınların sosyal gelişmişlik durumunun bu konuda hala belirleyici olduğu düşünülmüştür.

Keywords: Doğum öncesi bakım, Sosyodemografik faktörler, Kayseri,

\section{GİRIŞ}

Ana sağlığg hizmetle ri gebelik, doğum ve lohusalık dönemlerinde anne adayının, gerek hastalıktan korunma ve bakım, gerekse tedavi olma bağlamında gereksinim duyacağı tüm sağlık hizmetlerini kapsamaktadır. UNICEF (Birleşmiş Milletler Çocuklara Yardım Fonu) ve WHO (Dünya Sağlık Örgütü)'nün desteği ile 1952 yılında Türkiye’de Ana ve Çocuk Sağlığ 1 Hizmetleri örgütlenirken ana amaçlardan biri DÖB (Doğum Öncesi Bakım) hizmetlerinin verilmesini yerleştirmek olmuştur. Türkiye'de 1961 yılından sonra temel sağlık hizmetlerinin kapsamında ana ve çocuk sağlığ 1 , kişiye yönelik koruyucu sağlık hizmetlerinin bir parçası olarak diğer hizmetlere entegre edilmiştir (1).

Türkiyede ana sağlı̆̆ı ve aile planlaması hizmetlerinde yllar içinde önemli gelişmeler sağlandığ 1 bilinmektedir. Ancak anne ve çocuk sağlığ göstergelerinde istenilen düzeye gelinememiştir. 1998 Türkiye Nüfus ve Sağlık Araştırması (TNSA) gebelerin \% 68'inin en az bir kez sağlik personelinden doğum öncesi bakım aldığını göstermektedir. Bu oran 1988 TNSA'daki \% 43 ve 1993 TNSA'daki \% 63'e göre gelişme sağlandığını göstermektedir $(2,3)$.

Anne sağlığ1 hizmetlerinde hedef grup olan 1549 yaş kadın sayısı ülkemizde nüfusun \%27,4'ü olup, 2001 nüfus verilerine göre yaklaşık 18 milyondur (4). Türkiye'de yılda yaklaşı 1,5 milyon doğum olduğu ve bunlarında üçte birinin hiç doğum öncesi bakım almadığ 1998 TNSA'da tespit edilmiştir (2).

Gebelikte annenin karşılaştığı risk faktörlerinin kontrol altına alınmadığ 1 durumlarda hem annenin hem de bebeğin yaşamları tehlike altına girmektedir. Anne ve bebeğin sağlığını önemli ölçüde etkileyen riskler

$\begin{array}{llll}\text { İletişim: } & \begin{array}{l}\text { Dr. Ayşegül Erdoğan. KSÜ Tip Fakültesi Halk Sağlığı } \\ \text { Anabilim Dalı, Kahramanmaraş }\end{array} & \begin{array}{l}\text { Tel } \\ \text { E-Posta }\end{array} & : \text { draysegulerdogan@gmail.com } \\ & & \text { Geliş Tarihi : } 27.06 .2019\end{array}$


koruyucu bir sağllk hizmeti olan DÖB ile önlenebilecektir. Annenin yaşının 18'in altında ya da 35 'in üzerinde olması, gebelik aralığının 2 yıldan kısa olması, toplam dörtten fazla sayıda gebelik ya da doğumun gerçekleşmiş olması anne ve bebek ölümleri ile doğrudan ilişkili riskli durumlardir (5).

Gebelik fizyolojik bir olay olmasına rağmen azımsanamayacak sayıda olguda komplikasyonlar nedeniyle anne ve fetusun sağlığ tehlikeye girmektedir. İyi bir doğum öncesi bakım ile risk altında olan anneler belirlenerek, anne ve bebeklerin önlenebilir nedenlerden dolayı ölmeleri engellenebilir (6). Prenatal bakımda amaç mümkün olduğunca komplikasyonsuz bir gebelik sağlamak ve bu süreci canlı ve sağlıklı bir bebeğin doğması ile sonuçlandırmaktır. Gebelik döneminde yapılacak olan izlemler sırasında hekimin ve diğer sağlık personelinin yapması gerekenlerin başında gebelik sırasında oluşabilecek normal değişikliklerin belirlenmesi, tıbbi ve patolojik durumların erken tespiti ve olumsuz etkilerin en aza indirilmesi gelir. Doğum öncesi dönemde, anne adayında oluşabilecek sağlık sorunlarının saptanması ve tedavisi yanında gebelik bakımı konusunda anne adayını bilgilendirmek en önemli amaçlardan birisidir $(6,7)$.

Prenatal bakımdan yararlanmanın doğru olarak belirlenmesi etkin bir prenatal bakımla ilgili halk sağlığı programlarının geliştirilmesinde en önemli adımdır (8, 9). Ülkemizde DÖB hizmetleri, birinci ve ikinci basamak sağlık kuruluşları, üniversite hastaneleri ve özel sektör gibi çeşitli ve çok sayıda birim tarafından verilmektedir.

Kayseri İli’nde yürütülen bu çalışmanın amacı kadınların doğum öncesi bakım alma düzeyinin belirlenmesi ve doğum öncesi bakımın yeterliliğini etkileyen faktörlerin saptanmasıdır.

\section{GEREÇ VE YÖNTEMLER}

Kayseri İlinde yapılan bu tanımlayıcı çalışmada, il merkezinde doğum yapan kadınların doğum öncesi bakım hizmetleri değerlendirilmiştir. Araştırma evrenini Kayseri İl merkezinde 2002 yılında canlı doğum yapan kadınlar oluşturmaktadır. Kayseri İli 2000 yılı nüfusu 1,058,354 kişi olup İl Sağlık Müdürlügü kayıtlarına göre $15-49$ yaş kadın nüfus 293,536 (toplam nüfusun \% 27,7'si) $\operatorname{dir}(10)$.

Araştırma örneklemine; Doğumevi, SSK (Sosyal Sigortalar Kurumu), Tip Fakültesi, üç özel hastane (Özel Hayat Hastanesi, Özel Ömür Hastanesi, Özel Melikgazi Hastanesi), Kayseri İl merkezindeki sağlı ocağ bölgelerinden; evde sağlık personeli yardımı ile ve evde sağlık personeli yardımı olmadan doğum yapan kadınlar alınmıştır. Gebelik süresini Kayseri İli dışında geçirenler araştırma kapsamına alınmamıştır.

Kayseri İlinde doğumların \% 94,9'u hastanelerde, \% 3,6'sı sağlık personeli ile evde, \% 1,5'i kendi kendine ya da sağlık personeli dışındaki kişiler yardımıyla olmaktadır. Hastanede gerçekleșen doğumların yaklaşık \% 50'si Doğumevinde \% 30'u SSK hastanesinde, \% 8'i Tip Fakültesi hastanesinde, \% 5’i Özel hastanelerde gerçekleşmektedir (10). Bu oranlar dikkate alınarak her bir kurumdan örneğe alınacak kadın sayısı belirlenmiştir. Kayseri İl Sağlık Müdürlüğü kayıtlarından yararlanılarak araştırma dönemindeki tespit edilen sağlık personeli yardımıyla evde ve sağlik personeli olmadan evde gerçekleşen doğumlar araştırmaya alınmıştır.

Örnek büyüklüğü hesaplanırken, Türkiye'de İç Anadolu Bölgesinde doğum öncesi dönemde en az bir kez bakım alma oranı olarak \% 75 alınmıştır (3). Araştırmada örnek büyüklüğü $\% 95$ güven düzeyinde, $\% 80$ güç ile $\% 7$ toleransla 501 kişi olarak hesaplanmıştır (11). Araştırma kapsamına 650 kadının alınması hedeflenmiştir. Ankete katılmayı kabul etmeme, evde sağlık personeli ile gerçekleşen doğumlara ulaşmadaki güçlük ve ayrıca SSK hastanesinde kadınların doğum sonrasında hastanede kısa süreli kalması nedeniyle 627 kadına ulaşılmış olup ulaşma oranı \% 96,5'dir. Çalışmanın gücü \% 87 olarak bulunmuştur.

Daha uzun süreyi kapsamasını sağlamak amacıyla veri toplama iki ayrı dönemde Haziran-Temmuz 2002 ve Ekim-Kasım 2002 tarihleri arasında yapılmıștır. Veri toplama yöntemi olarak anket formu kullanılmıştır. Hazırlanan anketin anlaşılabilirliği ve işleyişini kontrol etmek amacı ile toplam 20 kadına ön anket uygulanmış ve gerekli düzenlemeler yapıldıktan sonra anket formuna son şekli verilmiştir.

Vajinal yolla doğum yapan kadınlarla doğumdan en az 4 saat, sezaryen ile doğum yapan kadınlardan en az 12 saat sonra görüşülmüştür. Görüşme her bir kadın için ortalama 20 dakika sürmüştür. Anketlerin tümü araştırmacı tarafından yüz yüze görüşme ile gerçekleştirilmiştir. Anket formunda kadının sosyodemografık özellikleri, doğurganlık özellikleri, bu gebeliğinde doğum öncesi bakını alma durumu ve aldığg hizmetlere yönelik sorular yer almıştır.

Ailenin aylık gelir durumunun belirlenmesinde, evdeki bireylerin toplam kazancı sorulmuştur. Asgari ücret (2002 y1lı 220 milyon) ve altında alanlar düşük gelirli, 221-499 milyon orta, 500 milyon ve üzeri yüksek gelirli olarak kabul edilmiştir. Sosyal güvence durumunda yeşil kart sosyal güvenceye dahil edilmemiştir. Kadının eșiyle kuzen olmaları birinci dereceden akraba, diğerleri ikinci dereceden akraba olarak kabul edilmiştir.

Yeterli doğum öncesi bakım alma durumu TNSA kriterine göre değerlendirilmiştir. TNSA kriterine göre; ilk trimesterde izleme başlama ve toplam $6 \mathrm{kez}$ bakım alma yeterli, bunun dıșındakiler yetersiz DÖB alma olarak değerlendirilmiştir (3).

\section{İstatistiksel çözümleme}

Veriler bilgisayar ortamında değerlendirilmiştir. İstatistiksel analizde; Ki-kare, testi ve çok değişkenli analizde, Lojistik regresyon analizi (Enter model) kullanılmıştır. Aritmetik ortalamalar standart sapma değerleri ile birlikte gösterilmiştir. Değerlendirmelerde $p<0.05$ değerleri anlamlı kabul edilmiştir.

\section{Araştırmanın Etik Yönü}

Araştırma için ilgili kurum ve kuruluşlardan gerekli izinler alınmıştır. Görüşmeler yapılmadan önce katılımcılardan sözel onay alınmıştır.

\section{BULGULAR}


Araștırma grubuna alınan 627 kadının doğumları büyük oranda doğumevinde (\% 53) gerçekleşmiştir. Doğumların sadece \% 2,4'ü sağlık personeli olmadan evde meydana gelmiştir.

Araştırma grubuna alınan 627 kadının yaş ortalaması 25,5 $\pm 5,2$ bulunmuştur. İlk evlenme yaşı ortalamaları 19,7 \pm 3.2 olup (ortanca 19), ilk gebelik yaşı ortalamaları ise $20,4 \pm 3,3$ (ortanca 20) olarak bulunmuştur. Kadınların son doğumları incelendiğinde; $\% 71,5^{\prime}$ inin spontan vajinal veya müdahaleli vajinal doğum, \% 28,5'inin sezaryen ile doğum yaptıkları saptanmıştır. Doğumların 12'si (\% 1,9) çoğul gebeliktir.

Kadınların çoğunluğu $(\%$ 82,5) 20-34 yaş grubunda yer almıştır. Eğitim durumlarına bakıldığında ilk ve orta okul mezunu olan kadınların oranı $\% 67,2$, ilk ve orta okul eğitimli eş oranı \% 61,3 iken lise ve üzeri eğitimli kadın \% 20,7'dir. Lise ve üzeri eğitimli eşlerin oranı \% 34,4'dür. Araştırma grubundaki kadınların \% 94,7'si ev hanımıdır. Kadınların \% 41'inin ilk doğumu iken \% 10,8 'i dört ve daha fazla doğum yapmıştır. İlk doğumlar hariç tutulduğunda iki yıldan daha az doğum aralığı olan kadınlar \% 18,9 olarak saptanmıștır. İki veya daha çok doğum yapmış olan 370 kadının doğum aralığı ortalaması $46,7 \pm 29,8$ ay olarak bulunmuştur. Kadınların \% 69,2'sinin kentsel alanda yaşadıkları, \% 40,2'sinin geniş aileye sahip oldukları saptanmıştır. Kentte yaşayanlarda geniş aile oranı \%35,7, kırda yaşayanlarda \% 50,3 olup aradaki fark istatistiksel açıdan önemli bulunmuştur ( $x=11,75$ $\mathrm{p}<0,001)$. Kadınların \% 93,9'unun resmi nikahı vardır. Kadınların eşleriyle akrabalık derecesine bakıldığında \% 9,5'inin akraba oldukları saptanmış olup, birinci derecede akraba evliliği olanların oranı \% 11,3'dür. Ailelerin dört de birinin geliri düşük iken, dört de birinin gelir düzeyi yüksek bulunmuştur (Tablo 1).

Araştırma grubundaki kadınların \% 97,5'i en az bir kez doğum öncesi bakım almıştı. Kadınların \% 70,2'si altı ve daha fazla kez bakım almışlardı. Kadınlara gebelikleri sırasında ilk ne zaman bakım almaya başladıkları sorulduğunda; \% 78,1'i ilk trimesterde, \% $16,5^{\prime} \mathrm{i}$ ikinci trimesterde aldığını ifade ederken, \% 5,4'ü üçüncü trimesterde aldıklarını ifade etmişlerdir. TNSA'ya göre, birinci trimesterde bakıma başlama toplam 6 kez bakım alma yeterli doğum öncesi bakım olarak değerlendirildiğinde; kadınların \% 62,4’ünün yeterli doğum öncesi bakım aldığı, ilk trimesterde bakıma başlamama veya 5 den daha az bakım alanlar yetersiz olarak değerlendirildiğinde \% 37,6'sının yetersiz doğum öncesi bakım aldığı bulunmuştur.

Kadınların yaş gruplarına göre yeterli DÖB alma durumu değerlendirildiğinde yeterli bakım alma durumu 20-34 yaş grubu kadınlarda anlamlı ölçüde yüksek bulunmuştur $(\mathrm{p}<0,01)$. DÖB alma durumu hem kadın hem de eşinin eğitim düzeyine göre farklılık göstermektedir. Eğitim düzeyi yükseldikçe yeterli doğum

Doğum sırası arttıkça yeterli DÖB oranı istatistiksel açıdan önemli ölçüde azalmaktadır. Tüm gruplar birbirinden farklı olup 4 veya daha çok doğum yapanlarda bu oran \% 33.8 ile en düşük bulunmuştur $(\mathrm{p}<0,001)$. Yeterli DÖB alma oranı, doğum aralığı iki veya öncesi bakım alma oranı artmıştır $(\mathrm{p}<0,001)$.

Tablo 1. Araștırma grubunun tanımlayıcı özellikleri

\begin{tabular}{|l|l|l|}
\hline Özellikler $(\mathrm{n}=627)$ & Say1 & $\%$ \\
\hline Yaş grupları & 68 & 10,8 \\
\hline $15-19$ & 517 & 82,5 \\
\hline $20-34$ & 42 & 6,7 \\
\hline $35+$ &
\end{tabular}

Kadının eğitimi

\begin{tabular}{|l|l|c|}
\hline İlkokul alt1 & 76 & 12,2 \\
\hline İlkokul & 344 & 54,8 \\
\hline Ortaokul & 77 & 12,3 \\
\hline Lise & 96 & 15,3 \\
\hline Yüksekokul/Üniversite & 34 & 5,4
\end{tabular}

\section{Eşinin eğitimi}

\begin{tabular}{|l|l|c|}
\hline İlkokul altı & 27 & 4,3 \\
\hline İlkokul & 312 & 49,8 \\
\hline Ortaokul & 72 & 11,5 \\
\hline Lise & 157 & 25,0 \\
\hline Yüksekokul/Üniversite & 59 & 9,4 \\
\hline
\end{tabular}

\begin{tabular}{|l|l|r|}
\hline Kadının çalışma durumu & \multicolumn{3}{l}{} \\
\hline Çalışıyor & 33 & 5,3 \\
\hline Ev hanımı & 594 & 94,7 \\
\hline Dogn
\end{tabular}

\section{Doğum sırası}

\begin{tabular}{|l|l|l|}
\hline 1 & 257 & 41,0 \\
\hline $2-3$ & 302 & 48,2 \\
\hline 4 ve üzeri & 68 & 10,8 \\
\hline
\end{tabular}

Doğum aralığı $(\mathbf{n}=370)$

\begin{tabular}{|l|l|l|}
\hline 2 yll altı & 70 & 18,9 \\
\hline 2 yl ve üzeri & 300 & 81,1 \\
\hline
\end{tabular}

\section{Gebeliği isteme durumu}

\begin{tabular}{|l|l|r|}
\hline İstiyordu & 460 & 73,4 \\
\hline Daha sonra istiyordu & 60 & 9,6 \\
\hline İstemiyordu & 107 & 17,0
\end{tabular}

\section{Yerleșim yeri}

\begin{tabular}{|l|l|l|}
\hline Kur & 193 & 30,8 \\
\hline Kent & 434 & 69,2 \\
\hline Aile tipi & 375 & 59,8 \\
\hline Çekirdek & 252 & 40,2 \\
\hline Geniş & \multicolumn{3}{|l|}{} \\
\hline Akraba evliliği & 11,3 \\
\hline Birinci derece & 71 & 8,2 \\
\hline İkinci derece & 51 & 80,5 \\
\hline Yok & 505 & 93,9 \\
\hline Resmi nikah & 589 & 6,1 \\
\hline Var & 38 & \\
\hline Yok & 157 & 25,0 \\
\hline Ailenin ortalama geliri & \multicolumn{3}{|l|}{} \\
\hline Düşük & 316 & 50,4 \\
\hline Orta & 154 & 24,6 \\
\hline Yüksek & \multicolumn{3}{|l|}{} \\
\hline Sosyal güvence & 511 & 81,5 \\
\hline Var & 116 & 18,5 \\
\hline Yok &
\end{tabular}


daha fazla olanlarda doğum aralığ iki yıldan az olanlara göre anlamlı ölçüde yüksek bulunmuştur $(\mathrm{p}<0,05)$.

Yeterli doğum öncesi bakım alma oranı, çalışan kadınlarda çalışmayanlara göre, isteyerek gebe kalanlarda istemeyenlere göre anlamlı ölçüde yüksek bulunmuştur $(\mathrm{p}<0,001)$.

Kentsel alanda yaşama, çekirdek aileye sahip olma, resmi nikahlı olma ve sosyal güvenceye sahip olma, yeterli doğum öncesi bakım alma oranı anlamlı ölçüde $\operatorname{artmiştır~}(\mathrm{p}<0,01)$.

Yeterli doğum öncesi bakım alma ile akraba evliliği arasında bir ilişki saptanmamıştır ( $\mathrm{p}>0,05)$. Gelir durumu ile yeterli doğum öncesi bakım alma arasında önemli bir ilişki vardır. Gelir düzeyi arttıkça yeterli doğum öncesi balcım alma oranı anlamlı ölçüde artmaktadır $(\mathrm{p}<0,001)$.

Bakım almayan $16 \quad\left(\begin{array}{lll}\% & 2,5\end{array}\right)$ kadının tümü doğumunu doğumevinde yapmıştı. Kadınların \% 56,3'ü kırsal alandadır, \% 62,5'inin (10 kadın) gelir düzeyi düşük, sadece birinin gelir düzeyi yüksek olarak bulunmuştur. Doğum öncesi bakım almayan kadınların hiç birinin sosyal güvenceye sahip değildi. Bu kadınların \% 25,5'inin resmi nikahı yoktu. Doğum öncesi hiç bakım almayan 16 kadından 6'sı maddi olanaksızlıktan, 5’i hem maddi olanaksızlıktan hem de sağlık kuruluşundan yararlanmada güçlük olduğundan, diğerlerinin ise ihtiyaç duymadığından veya doğum öncesi bakım almayı gerekli bulmadığından hizmet almadıklarını ifade etmişlerdir.

Tablo 2'de görüldüğü gibi; tüm değişkenler kontrol edildiğinde, yerleşim yeri, kadının eğitimi, eşin eğitimi, aile tipi, sosyal güvence ve gebeliğin istenme durumu yeterli doğum öncesi bakım almada önemli bir belirleyici iken, yaş grupları, kadının çalışma durumu, akraba evliliği, resmi nikah, ailenin gelir durumu ve doğum sırası yeterli doğum öncesi bakım almada belirleyici olmamaktadır.

Kentte yaşayanlar kırda yaşayanlara göre 2 kat daha fazla yeterli doğum öncesi bakım almıştır $(p<0,01)$. Okur yazar olmayan veya sadece okur yazar olan kadınlara göre, ilk veya ortaokulu bitirenler önemli bir fark yaratmazken, lise ve üzeri eğitimli kadınlarda yeterli doğum öncesi bakım alma olasılığ 13,5 kat daha fazladır $(p<0,001)$. Eşin eğitimi de benzer şekilde önemli bir belirleyicidir. Eşi lise ve üzeri eğitimli kadınlar eğitimsizlere göre yeterli doğum öncesi bakım alma olasılığ 3,3 kat daha fazladır $(\mathrm{p}<0,05)$.

Aile tipi, sosyal güvence ve gebeliği isteme durumu yeterli doğum öncesi bakım almayı anlamlı ölçüde etkilemektedir. Yeterli doğum öncesi bakım alma olasılığ geniş aile yapısı olanlara göre çekirdek ailelerde anlamlı olarak 1,5 kat fazladır $(\mathrm{p}<0,05)$. Sosyal güvencesi olmayan kadınlara göre, olanlarda yeterli doğum öncesi bakım alma 1,8 kat yüksek bulunmuştur $(\mathrm{p}<0,001)$. Gebeliğin isteme durumu, istemeyenlere göre yeterli doğum öncesi bakım almayı 3,5 kat artırmıştır $(\mathrm{p}<0,001)$.

\section{TARTIŞMA}

Bu çalışmada Kayseri İl düzeyinde doğum öncesi bakım alma durumu değerlendirilmiştir. Çalışmamızda kadınların erkeklere göre daha az eğitimli oldukları saptanmıştır. Çalışmada, ortaokul ve üzeri eğitimli kadınların oranı \% 33,0, eşlerin ise \% 45,9 olarak bulunmuştur. Kadının statüsünü ve aile içindeki yerini belirlemede önemli bir gösterge olan kadının çalışma durumu değerlendirildiğinde araştırma grubunda çalışan kadın oranı \% 5,3'dür. Türkiye genelinde TNSA 1998'e göre son beş yıl içindeki doğumların \% 19'u istenmemiş, $\% 11$ 'i daha sonra istenmiş doğumlardır (3). Bu çalışmada, kadınların \% 17'si bu gebeliğini istemediğini, \% 9,6'sı ise daha sonra istediğini ifade etmiştir. Çalışmada bulunan bu oran ülke geneline göre daha düşük bulunmuştur (Tablo 1).

Türkiyede nüfusun tamamının sosyal güvence kapsamında olmaması önemli bir sorundur. Bu çalışmada, kadınların \% 18,5’inin sosyal güvencesi olmadığı bulunmuştur. Doğumsal anomaliler açısından büyük bir sorun oluşturan akraba evlilikleri oranı ülkemizde \% 2025 arasında değişmektedir (12). Araştırma grubunda bu oran \% 19,5 ile benzer olarak bulunmuştur.

Gelişmiş ülkelerle kıyaslandığında doğum öncesi bakımın ülkemizde yeterli düzeyde olmadığı bir gerçektir. Dünyada doğum öncesi bakım alma durumları incelendiğinde; en az bir kez bakım oranı gelişmiş ülkelerde \% 99-100, gelişmekte olan ülkelerde \% 69 ve az gelișmiş ülkelerde ise \% 55 dür (13). Ülkemizde ise doğum öncesi bakım hizmetlerinden en az bir kez yararlanma oranı \% 68,1'dir. Bu oran bölgeler arasında farklılık göstermektedir. Doğu İllerimizde \% 38, Batı İllerimizde \% 86, İlimizin de içinde bulunduğu İç Anadolu bölgesinde \% 75 gibi farklı oranlardadır (3). Bu araştırmada en az bir kez doğum öncesi bakım alanların oranı \% 97,5 olarak bulunmuştur. Bu oranın ülke genelinden yüksek olması çalışmanın kent merkezinde yapılmasından kaynaklanabilir. Nitekim İstanbul, Manisa, Tekirdağ, Konya ve Zonguldak İllerini kapsayan ve kentsel alanda yapılmış bir çalışmada, en az bir kez DÖB alma oranı \% 92,4 bulunmuştur (14). Kayseri Doğumevinde doğum yapmış olan kadınlarla ile ilgili yapılan bir çalışmada, en az bir kez doğum öncesi bakım alanların oranı benzer şekilde \% 95,4 olarak bulunmuştur (15). Sivas doğumevinde yapılan bir çalışmada, bu oran \% 95,2, Ankara’da yapılan çalıșmada \% 92,1, Çanakkale'de yapılan çalışmada \% 83 bulunmuştur (16-18). Antalya'da gebe takip kartlarından yapılan çalışmada, kadınların \% 97,7'sinin, Gaziantep İl merkezinde sağlık ocaklarına başvuran kadınlarda yapılan bir araştırmada \% 76'sının en az bir kez bakım aldıkları gösterilmiştir $(19,20)$.

Bir çok ülkede doğum öncesi bakım hizmetleri kantitatif olarak yani bakım sayısı dikkate alınarak değerlendirilmektedir. DÖB hizmetlerinin değerlendirilmesinde ülkeler kendi belirledikleri ya da WHO'nun belirlediği bakım kriterlerini kullanmaktadır. İlk trimesterde tespit ve toplam 6 kez bakım alanlar yeterli doğum öncesi bakım alma olarak kabul edildiğinde, bu oran, 1993-1998 arası 5 yıllık süreçte \% 29'luk bir artış göstermiştir (3). Aynı kriterleri kullanarak yeterliliğin hesaplandığı bu çalışmada, yeterli bakım alma oranı $\%$ 62,4 ile Türkiye ortalamasının üstünde bulunmuștur (Tablo 2). İzmir'de yapılan benzer bir çalışmada da bu oran \% 84,8 bulunmuştur (21). Erbaydar'ın 4 ve üzeri bakım alanların yeterli bakım almış olarak kabul edildiği çalışmasında, yeterli bakım alma oranı yoksul 
Tablo 2. TNSA kriterlerine göre doğum öncesi bakımın yeterliliğini etkileyen faktörler

\begin{tabular}{|c|c|c|c|c|c|c|}
\hline \multicolumn{7}{|c|}{ Yeterli DOB Alan } \\
\hline Özellikler & $\mathbf{n}$ & Sayı & $\%$ & OR & \%95 CI & $\mathbf{p}$ \\
\hline Toplanı & 627 & 391 & 62,4 & & & \\
\hline \multicolumn{7}{|l|}{ Yerleşim yeri } \\
\hline Kur & 193 & 98 & 50,8 & 1,00 & & \\
\hline Kent & 434 & 293 & 67,5 & 2,00 & $1,33-3,03$ & $0,01^{*}$ \\
\hline \multicolumn{7}{|l|}{ Yaş grupları } \\
\hline $15-19$ & 68 & 35 & 51,5 & 1,00 & & \\
\hline $20-34$ & 517 & 338 & 65,4 & 1,56 & $0,83-2,92$ & 0,16 \\
\hline $35+$ & 42 & 18 & 42,9 & 1,00 & $0,35-2,86$ & 0,99 \\
\hline \multicolumn{7}{|l|}{ Kadının eğitimi } \\
\hline İlkokul altı & 76 & 26 & 34,2 & 1,00 & & \\
\hline İlkokul+Ortaokul & 421 & 249 & 59,1 & 1,34 & $0,69-2,58$ & 0,37 \\
\hline Lise ve üstü & 130 & 116 & 89,2 & 3,53 & $1,39-8,91$ & $0,001^{\star}$ \\
\hline \multicolumn{7}{|l|}{ Eşinin eğitimi } \\
\hline İlkokul altı & 27 & 6 & 22,2 & 1,00 & & \\
\hline İlkokul+Ortaokul & 384 & 210 & 54,7 & 2,37 & $0,77-7,31$ & 0,13 \\
\hline Lise ve üstü & 216 & 175 & 81,0 & 3,37 & $1,00-11,27$ & $0,04^{*}$ \\
\hline \multicolumn{7}{|l|}{ Çalışma durumu } \\
\hline Ev hanımı & 594 & 360 & 60,6 & 1,00 & & \\
\hline Çalışıyor & 33 & 31 & 93,9 & 0,56 & $0,11-2,72$ & 0,47 \\
\hline \multicolumn{7}{|l|}{ Aile tipi } \\
\hline Çekirdek & 375 & 250 & 66,7 & 1,53 & $1,00-2,33$ & $0,04^{*}$ \\
\hline Geniş & 252 & 141 & 56,0 & 1,00 & & \\
\hline \multicolumn{7}{|l|}{ Sosyal güvence } \\
\hline Var & 308 & 232 & 75,3 & 1,84 & $1,17-2,89$ & $0,001^{*}$ \\
\hline Yok & 319 & 159 & 49,8 & 1,00 & & \\
\hline \multicolumn{7}{|l|}{ Akraba evliliği } \\
\hline Yok & 505 & 319 & 63,2 & 1,00 & & \\
\hline Var & 122 & 72 & 59,0 & 0,79 & $0,49-1,28$ & 0,34 \\
\hline \multicolumn{7}{|l|}{ Resmi nikah } \\
\hline Var & 589 & 375 & 63,7 & 1,67 & $0,49-2,43$ & 0,81 \\
\hline Yok & 38 & 16 & 42,1 & 1,00 & & \\
\hline \multicolumn{7}{|c|}{ Ailenin ortalama gelir } \\
\hline \multicolumn{7}{|c|}{ durumu } \\
\hline Düşük & 157 & 75 & 47,8 & 1,00 & & \\
\hline Orta & 316 & 186 & 58,9 & 0,85 & $0,52-1,38$ & 0,52 \\
\hline Yüksek & 154 & 130 & 84,4 & 1,67 & $0,79-3,52$ & 0,17 \\
\hline \multicolumn{7}{|l|}{ Doğum sırası } \\
\hline 1 & 256 & 182 & 71,1 & 1,62 & $0,73-3,57$ & 0,23 \\
\hline $2-3$ & 303 & 186 & 61,4 & 1,36 & $0,69-2,69$ & 0,36 \\
\hline $4+$ & 68 & 23 & 33,8 & 1,00 & & \\
\hline \multicolumn{7}{|c|}{ Gebeliği isteme durumu } \\
\hline İstiyordu & 460 & 328 & 71,3 & 3,53 & $2,21-5,64$ & $0,001^{*}$ \\
\hline İstemiyordu & 167 & 63 & 37,7 & 1,00 & & \\
\hline
\end{tabular}

${ }^{\star}$ Etkili değişkenler 
mahallelerde $\% 63,8$ ve varsıl mahallelerde $\% 86,5$ olarak bulmuştur (14). Çalışmamızda ve diğer iki çalışmada bu oranın ülke genelinden yüksek olması, kent merkezinde yapılmış olmasından kaynaklanmış olabilir. Benzer kriteri kullanılarak gebe izlem kartlarının değerlendirildiği başka çalışmalarda, izlenen gebelerin DÖB yeterlilik oranı sırasılyla \% 34,7 ve \% 41,2 olarak çalışmamızdan düşük bulunmuştur $(22,23)$.

Çalışmamızda yeterli doğum öncesi bakım alma durumunu etkileyen faktörler incelendiğinde; kadının yaşı, kadının ve eşinin eğitimi, kadının çalışma durumu, aile tipi, yerleşim yeri, resmi nikah durumu, ailenin gelir ve sosyal güvence durumu, doğum sırası, doğum aralığı ve gebeliği isteme durumu ile yeterli doğum öncesi bakım alma arasında istatistiksel olarak anlamlı bir ilişki bulunmuştur (Tablo 2). Kadınların eğitim durumu prenatal bakım almada belirleyici olmaktadır. Nitekim çalışmamızda eğitim düzeyi arttıkça prenatal bakım alma artmıştır. Bu oran lise ve üzeri eğitimli kadınlarda $\% 89,2$, ilk ve ortaokul eğitimli kadınlarda \%59,1 iken eğitimi olmayan kadınlarda \% 34,2 bulunmuştur. Kadınların eşlerinin eğitim düzeyinin yüksekliği de yeterli doğum öncesi bakım almayı artırmıştır.

Ülkemizde son yllarda giderek daha fazla vurgulandığı ve sağlık alanında yapılan pek çok araştırmada ortaya konduğu gibi; kadının statüsü genel sağlık konusundaki bilgi, tutum ve davranışlarını ve hizmetlerden yararlanmasını etkileyen önemli bir faktördür (3). Nitekim yeterli doğum öncesi bakım alma oranı, çalışan kadınlarda \% 93,9, resmi nikahı olanlarda ise \% 63,7 olarak saptanmıştır. Bu nedenle doğum öncesi bakım hizmetlerinde kadın ve bebeğin sağlığının korunmasında sosyal boyutun göz ardı edilmemesi gerekir.

Araştırma grubundaki 16 kadın hiç doğum öncesi bakım almamıştır. Bu kadınların \% 56,3'ünün kırsal alanda yaşadığı,$\% 25$ 'inin adölesan yaş grubunda olduğu, \% 37,5’inin eğitimi olmadığı, \%6 2,5'inin düşük gelire sahip olduğu, \% 25'inin resmi nikahı olmadığı bulunmuştur. Bu kadınların yarısının yeşil kartı olduğu, yarısının da sağlık güvencesinin olmadığı bulunmuştur. Doğum öncesi bakım almayan kadınlara bakım almama nedenleri sorulduğunda; üçte biri maddi olanaksızlıktan, üçte biri hem maddi olanaksızlıktan hem de sağlık kuruluşundan yararlanmada güçlükolduğundan, diğerleri ise doğum öncesi bakım almayı gerekli bulmadığından hizmet almadıklarını ifade etmişlerdir. Ülke genelinde kadınların \% 63'ünün ihtiyaç duymama, \% 16'smın maddi olanaksızlıklar nedeniyle bakım almadıkları saptanmıştır (3). Erbaydar'n çalışmasında şikayetin olmaması ve maddi olanaksızlıklar, yararlanmama nedeni olarak belirtilmiştir (14). Bir başka çalışmada yararlanmamada en önemli nedenler sağlık kuruluşlarının uzaklığı ve sağlık elemanlarının ilgisizliği olarak gösterilmiştir (24).

$\mathrm{Bu}$ çalışmada TNSA kriterine göre lojistik regresyon analiziyle incelendiğinde; yerleşim yeri, kadının eğitimi, eşin eğitimi, aile tipi, sosyal güvence ve gebeliğin istenme durumu yeterli doğum öncesi bakım almada önemli belirleyici iken, yaş grupları, kadının çalışma durumu, akraba evliliği, resmi nikah, ailenin gelir durumu ve doğum sırası yeterli doğum öncesi bakım almada belirleyici olmamaktadır (Tablo 2). Ülkeyi temsil eden TNSA2008'de, kadının yaşadığı bölge, kadının eğitimi, eşin eğitimi, sosyal güvence, yaş grupları, doğum sırası ve resmi nikah yeterli doğum öncesi bakım almada önemli belirleyiciler olarak bulunmuştur (3).

Çalışmada; kentsel alanda yaşayanlar kıra göre 2, lise ve üzeri eğitim alanlar eğitim almayanlara göre 3,5 , eşi lise ve üzeri eğitim alanlar eğitim almayanlara göre 3,3, çekirdek aileler geniş ailelere göre 1,5, sosyal güvencesi olanlar olmayanlara göre 1,8 ve gebeliği isteyenler, istemeyenlere göre 3,5 kat daha fazla yeterli doğum öncesi bakım almışlardır. TNSA 1998 ileri analiz sonuçlarında ise, yerleşim yeri belirleyici olmazken bölgeler etkili bulunmuştur. Ayrıca çalışmamızdan farklı olarak gebeliği isteme durumu etkili olmazken, kadının yaşı, doğum sırası ve resmi nikahlı olması yeterli doğum öncesi bakım almada etkili bulunmuştur. Çelik'in 1993 TNSA sonuçlarını kullanarak yaptığı lojistik regresyon analiz çalışmasında, bölge, kadının eğitimi, doğum sırası, sosyal güvence, doğum öncesi balcım hizmeti kullanmayı etkileyen faktörler olarak doğum öncesi bakım hizmeti kullanmayı etkileyen faktörler olarak bulunmuştur (25) .

Araştırmanın en önemli kısıtlllığ 1 verilerin eski bir tarihe dayalı olmasıdır. Çalışmanın bir tıpta uzmanlık tezinden türetilmiş olması nedeniyle üzerinde çok fazla değişiklik ve güncelleme yapılmamıştır. Bir diğer kısitlılık verilerin anketle toplanması olup hafıza faktörleri sonuçlara etki etmiş olabilir. Zaman ve kaynak sıkıntısı nedeniyle tüm evrene ulaşılamamış olup çalışma belirlenen örneklem üzerinde yürütülmüştür.

Çalışmamız 2000 yıllarının başlarında yapılmış olması nedeniyle bu dönemdeki DÖB hizmetlerinin bir fotoğrafı niteliğgindedir. Çalışmanın yapıldığı tarihten bugüne DÖB hizmetleri açısından ülkemizde önemli ilerlemeler olmuştur. 5 yılda bir yapılan TNSA 2003'de 4 ve üzeri DÖB alma oranı \% 53,9, 2008'de bu oran \% 73,7'ye, 2013 TNSA verilerine göre ise bu oran \% 88,9'a yükselmiştir (26-28). Sonuç olarak DÖB hizmetlerinin kullanımında kadının statüsünün geçmişte oldukça önemli olduğu, yıllar içinde de kadınların sosyal gelişmişlik durumunun bu konuda hala belirleyici olduğu düşünülmüştür.

\section{KAYNAKLAR}

1. Bulut A. Doğum Öncesi Bakım. İn: Neyzi O (Ed). Anne ve Çocuk Sağlığında Öncelikler. (2.Baskı). Nobel Tip Kitabevleri 1994, ss 7-36.

2. Hacettepe Nüfus Etütleri Enstitüsü Türkiye Nüfus ve Sağlık Araştırması, 1998. Hacettepe Nüfus Etütleri Enstitüsü, Sağlık Bakanlığı Ana Çocuk Sağlığı ve Aile Planlaması Genel Müdürlüğü, Ankara, Türkiye.

3. Hacettepe Üniversitesi, TAP Vakfı ve UNFPA. Türkiye’de Ana Sağlığı, Aile Planlaması Hizmetleri ve İsteyerek Düşükler. Türkiye Nüfus ve Sağlık Araştırması-1998 İleri Analiz Sonuçları. Ankara 2002, ss 183-241.

4. Türkiye Cumhuriyeti Sağlık Bakanlığı. Sağlık İstatistikleri 2001, ss 17-9.

5. Sağlık Bakanlığ 1 Ana Çocuk Sağlığı ve Aile Planla- 
ması Genel Müdürlüğü. Aile Planlaması Temel Bilgiler. İnsan Kaynağını Geliştirme Vakfı, İstanbul 1997, ss 5-15.

6. Taylor CM, Pernoll ML. Normal Pregnancy \& Prenatal Care. In: Pernoll ML (Ed). Current Obstetric \& Gynecologic Diagnosis \& Treatment (7th. ed). Appleton \& Lange, California 1991, pp 179-197.

7. Kochenour NK. Normal Gebelik ve Prenatal Bakrm. In: Scott JR, Disaia PJ, Hammond CB, Spellacy WN (Eds). Danforth Obstetrik ve Jinekoloji (7. Baskı). (Çev Ed: Erez SE). J.B. Lippncott Company \& Yüce Yayım A.Ş. İstanbul 1997, ss 67-104.

8. Kotelchuck M. An evaluation of the Kessner adequacy of prenatal care index and a proposed adequacy of prenatal care utilization index. Ani J Public Health 1994; 84: 1414-19.

9. Alexander GR, Kotelchuck M. Quantifying the adequacy of prenatal care: A comparison of indices. Public Health Rep 1996; 111: 408-18.

10. T.C. Sağlık Bakanlığı Kayseri Sağlık Müdürlüğü. Kayseri İstatistik Yılllğ 1 2001, ss 6-85.

11. Özdamar K. Modern Bilimsel Araştırma Yöntemleri. Kaan Kitabevi, Eskişehir 2003, ss 109-13.

12. Tunçbilek E. Clinical outcomes of consanguineous marriages in Turkey. Turk J Pediatr. 2001; 43: 277-9.

13. UNICEF: Dünya Çocuklarının Durumu. 2004, ss 130-36.

14. Erbaydar T. Utilization of prenatal care in poorer and wealthier urban neighbourhoods in Turkey. Eur J Public Health 2003; 13: 320-6.

15. Naçar M, Öztürk A, Öztürk Y. Doğum sonrası dönemde verilen aile planlaması eğitiminin yöntem kullanmaya etkisi. Erciyes Tip Dergisi 2003; 25: 12230.

16. Boz D G, Öztürk Y. Sivas Doğumevi hastanesinde doğum yapan kadınların doğum öncesi bakım ve doğuma ilişkin bilgi ve davranışlarının değerlendirilmesi. Erciyes Üniversitesi Sağlık Bilimleri Dergisi 2003; 12: 62-8.

17. Yildırım A, Maral I. The status of antenetal care attendanca of women livmg in a semi-urban and a urban area in Ankara. International Public Health Congress "Health 21 In Action" Abstract book İstanbul, Turkey 2000, p 28.

18. Kaya F G. Çanakkale Devlet hastanesine doğum yapmak için başvuran kadınların antenatal bakım alma durumlarının incelenmesi. Ege Üniversitesi Sağlık Bilimleri Enstitüsü Hemşirelik programı, Yüksek Lisans Tezi İzmir 1999, ss 61-5.
19. Etiler N, Aktekin M R, Çapar H. Antalya kent merkezindeki bir sağlık ocağı bölgesinde doğum öncesi bakım hizmetlerinin değerlendirilmesi. Sağlık ve Toplum 2000; 10: 41-5.

20. Bozkurt Aİ, Şahinöz S, Özçırpıcı B, Özgür S. Gaziantep’te sağlık ocaklarına herhangi bir nedenle başvuran 15-49 yaş evli kadınların doğum öncesi, doğum ve doğum sonrası bakım alma durumunun ve etkileyen faktörlerin değerlendirilmesi. Erciyes Tip Dergisi 2001; 23: 59-7.

21. Çiçeklioğlu M, Türk M. Bornova sağllk grup başkanlı̆g 1 bölgesinde gebelere verilen doğum öncesi bakım yeterliliği ve sürekliliğinin değerlendirilmesi. 8 . Ulusal Plalk Sağlığ Kongre Kitabı Diyarbakır 2002, s 484 .

22. Şahinöz S, Şahinöz T, Eker H.H, Ceyhan O. Gebe lohısa izleme kartlarından yararlanılarak gebe ve lohusa izlemlerinin değerlendirilmesi, Erciyes Üniversitesi Sağlık Bilimleri Dergisi 1998; 7: 44-50.

23. Çetinkaya F, Naçar M, Aslan A, Öztürk Y. Kayseride ebelerin gebe ve bebek izlemlerinin etkinliği. Türk Aile Hekimliği Dergisi 2004; 8: 14-9.

24. Güler K, Çoşkun A, Ekizler H, Karanisoğlu H, Tekin $\mathrm{N}$. Prenatal bakımı etkileyen faktörlerle ilgili epidemiyolojik bir çalışma. Hemşirelik Bülteni 1988; 12: 58-63.

25. Çelik Y, Hotchkiss R D. The socio-economic determinants of maternal health care utilization in Turkey. Social Science \& Medicine 2000; 12: 1797-806.

26. Hacettepe Nüfus Etütleri Enstitüsü, Türkiye Nüfus ve Sağlık Araştırması, 2003. Hacettepe Nüfus Etütleri Enstitüsü, Sağlık Bakanlığı Ana Çocuk Sağlığı ve Aile Planlaması Genel Müdürlüğü, Devlet Planlama Teşkilatı ve Avrupa Birliği, Ankara, Türkiye.

27. Hacettepe Üniversitesi Nüfus Etütleri Enstitüsü. Türkiye Nüfus ve Sağlık Araştırması, 2008. Hacettepe Üniversitesi Nüfus Etütleri Enstitüsü, Sağl1k Bakanlığı Ana Çocuk Sağlığı ve Aile Planlaması Genel Müdürlüğü, Başbakanlık Devlet Planlama Teşkilatı Müsteşarlı̆ğ ve TÜBİTAK, 2009, Ankara, Türkiye.

28. Hacettepe Üniversitesi Nüfus Etütleri Enstitüsü. "2013 Türkiye Nüfus ve Sağlık Araştırması". Hacettepe Üniversitesi Nüfus Etütleri Enstitüsü, T.C. Kalk Bakanlığı ve TÜBİTAK, 2014, Ankara, Türkiye. 